\title{
MENINGKATKAN HASIL BELAJAR SISWA MELALUI PENERAPAN MODEL PEMBELAJARAN KONTEKSTUAL (Contextual Teaching and Learning/CTL) MATERI JENIS BAHAN PAKAN DAN PAKAN TERNAK DIKELAS XII SMA NEGERI 1 KONTUKOWUNA
}

\author{
Oleh: \\ SUNARTO \\ Guru SMAN 1 Kontukowuna, Kaupaten Muna \\ E-mail:
}

\begin{abstract}
ABSTRAK: Penelitian ini bertujuan untuk: 1) Untuk meningkatkan hasil belajar siswa melalui penerapan model pembelajaran Kontekstual (Contextual Teaching and Learning/CTL) materi jenis perubahan sosial XII IPS 1 SMA Negeri 1 Kontukowuna, 2) Untukmeningkatkanaktivitasmengajar guru melalui penerapan model pembelajaran Kontekstual (Contextual Teaching and Learning/CTL) materi perubahan sosial XII IPS 1 SMANegeri 1 Kontukowuna, 3) Untuk meningkatkan aktivitas belajar siswa melalui penerapan model pembelajaran Kontekstual (Contextual Teaching and Learning/CTL) materi perubahan sosial XII IPS 1 SMANegeri 1 Kontukowuna. Jenis penelitian ini adalah penelitian tindakan kelas (classroom action research). Penerapan penelitian tindakan di dalam kelas diharapakan akan mampu mendorong guru untuk memiliki kesadaran diri melakukan refleksi dan kritik diri terhadap aktivitas pembelajaran yang diselenggarakan. Penelitian ini dilaksanakan sebanyak dua siklus dan setiap siklus terdiri dari dua kali pertemuan yang dilaksanakan pada semester ganjil tahun pelajaran 2018/2019 di kelas XII IPS 1 SMA Negeri 1 Kontukowuna dengan jumlah siswa sebanyak 19 orang. Hasil penelitian menunjukan bahwa aktivitas siswa terhadap proses pembelajaran, terjardi peningkatan dari 73,68\% dengan nilai ratarata 71,58 pada siklus I dan siklus II hasil belajar siswa meningkat menjadi 94,74\% dengan nilai rata-rata 80,53. Untuk aktivitas mengajar guru pada siklus I pertemuan pertama mencapai $66,67 \%$ dan pertemuan kedua meningkat menjadi $73,33 \%$, sedangkan pada siklus II pertemuan pertama mencapai $86,67 \%$ dan pertemuan kedua meningkat menjadi $100 \%$. Selanjutnya untuk peningkatkan aktivitas belajar siswa pada siklus I pertemuan pertama mencapai $60 \%$ dan pertemuan kedua meningkat menjadi $73,33 \%$, sedangkan pada siklus II pertemuan pertama mencapai 93,33\% dan pertemuan kedua meningkat menjadi $100 \%$. Dengan demikian, indikator kinerja yang ditetapkan dalam penelitian ini telah tercapai dengan dua siklus pembelajaran.
\end{abstract}

Kata Kunci: Model Pembelajaran Kontekstual tipe CTL, Aktifitas belajar, Hasil belajar.

\section{A. PENDAHULUAN}

Guru sebagai tenaga pendidik mempunyai tujuan utama dalam kegiatan pembelajaran di sekolah yaitu menciptakan suasana belajar yang menyenangkan, memotivasi siswa untuk senantiasa belajar dengan baik dan bersemangat sehingga berdampak pada pencapaian hasil belajar yang optimal. Namun masih banyak tenaga pendidik yang menggunakan metode konvensional secara monoton dalam kegiatan pembelajaran di kelas sehingga suasana belajar terkesan kaku dan didominasi oleh guru.

Pelajaran keahlian agribisnis ternak unggas pada hakekatnya adalah pelajaran yang sangat erat hubungan dengan kehidupan yang terjadi disekitar kita. Guru dituntut agar dapat menerapkan metode pengajaran yang 
bervariasi, tidak monoton sehingga dapat

Secara umum, kenyataan yang dapat dijumpai di SMA ,menunjukkan bahwa sebagian besar pembelajaran sosiologi diberikan secara klasikal dengan model pembelajaran yang berfokus pada pembelajaran konsep yang bersifat hafalan dan didominasi guru tanpa banyak melihat kemungkinan penerapan metode lain yang sesuai dengan jenis materi, bahan dan media yang tersedia. Akibatnya, siswa kurang berminat untuk mengikuti pelajaran yang diajarkan oleh guru tersebut yang membuat siswa merasa bosan dan tidak tertarik mengikuti pembelajaran sehingga tidak ada motivasi dari dalam dirinya untuk berusaha memahami apa yang diajarkan oleh guru, yang akan berpengaruh pada rendahnya hasil belajar siswa.

Kenyataan demikian juga terjadi di SMA Negeri 1 Kontukowuna. Berdasarkan pengamatan langsung yang dilakukan peneliti pada proses pembelajaran sosiologi di kelas XII-IPS 1 terlihat bahwa guru sosiologi menggunakan model pembelajaran yang berfokus pada pembelajaran konsep yang bersifat hafalan tanpa adanya upaya agar terjadi proses dalam diri siswa untuk memahami materi dengan baik. Selain itu pembelajarannya masih menggunakan system konvensional, dimana pembelajaran yang berlangsung masih didominasi metode ceramah dan pemberian tugas. Serta dalam pelaksanaanya guru memegangkendali serta menarik minat dalam belajar.

memegang peran aktif, akibatnya murid cenderung pasif dalam menerima informasi, pengetahuan dan keterampilan dari guru. Kondisi tersebut menjadi salah satu penyebab rendahnya hasil belajar siswa pada paket Keahlian Agribisnis ternak unggas di SMA Negeri 1 Kontukowuna. Hal ini dapat dilihat dari hasil ulangan harian materi pokok perubahan sosial. Semester ganjil tahun pelajaran 2018/2019 pada mata keahlian sosilogi. Dari 19 orang siswa kelas XII-IPS 1, hanya 11 orang $(57,89 \%)$ yang memperoleh nilai $\geq 70$, sedangkan 8 siswa memperoleh nilai di bawah 70 . Hal ini belum memenuhi Kriteria Ketuntasan Minimal (KKM) yang telah ditetapkan oleh SMANegeri 1 Kontukowuna yaitu minimal $80 \%$ siswa memperoleh nilai $\geq 70$.

Berdasarkan kenyataan tersebut, guru diharapkan dapat mengembangkan suatu model pembelajaran yang dapat memotivasi dan mengaktifkan siswa dalam mengikuti proses pembelajaran di kelas sehingga dapat meningkatkan hasil belajar siswa. Salah satu model yang menurut peneliti dapat digunakan untuk menarik minat siswa terhadap materi pelajaran dan mengajak siswa berperan aktif dalam pembelajaran adalah dengan penerapan model Pembelajaran Kontekstual (Contextual Teaching and Learning /CTL). Model pembelajaran kontekstual merupakan pembelajaran yang melibatkan siswa secara aktif dalam proses pembelajaran serta siswa 
didorong untuk berusaha menemukan sendiri apa yang seharusnya dipelajari, sehingga pengetahuan yang diperoleh siswa lebih bermakna karena siswa mengalami sendiri apa yang dipelajarinya.

Berdasarkan keunggulan model pembelajaran kontekstual (Contextual Teaching and Learning/CTL) dapat diyakinkan bahwa hasil belajar siswa pada materi jenis bahan pakan dan pakan ternak

\section{B. METODE PENELITIAN}

\section{Jenis dan Setting Penelitian}

Jenis Penelitian ini adalah Penelitian Tindakan Kelas yang disingkat PTK (Classroom Action Research). siswa kelas XII IPS 1 SMA Negeri 1 kontukowuna, yang berjumlah 19 siswa yang terdiri dari 15 siswa laki-laki dan 4 siswa perempuan.

\section{Rencana Tindakan}

Tahap Perencanaan: Kegiatan ini diawali dengan orientasi, yaitu studi pendahuluan sebelum tindakan penelitian dilaksanakan. Berdasarkan hal tersebut di atas maka disusunlah rencana tindakan yang hendak dilaksanakan berupa rencana pelaksanaan pembelajaran (RPP) selama proses pelaksanaan pembelajaran sosiologi dengan menggunakan model pembelajaran Kontekstual tipe CTL.

Tahap Pelaksanaan Tindakan: Tahap pelaksanaan tindakan yaitu melaksanakan skenario pembelajaran yang telah disusun dapat ditingkatkan melalui penerapan model pembelajaran kontekstual (Contextual Teaching and Learning/CTL). Oleh karena itu, peneliti melakukan penelitian dengan judul "Meningkatkan Hasil Belajar siswa Melalui Penerapan Model Pembelajaran Kontekstual (Contextual Teaching and Learning/CTL) Materi jenis bahan pakan dan pakan ternak dikelas XII SMANegeri 1 Kontikowuna".

sebelumnya pada perencanaan. Guru melaksanakan pembelajaran dengan menggunakan model pembelajaran Kontekstual.

Observasi dan Evaluasi: Pada tahap ini obsever mengobservasi segala tindakan atau aktivitas yang telah dilakukan oleh guru dengan menggunakan lembar observasi dalam proses pembelajaran Sosiologi dengan menerapkan model pembelajaran Kontekstual tipe CTL. Pada setiap akhir tindakan diadakan tes untuk mengetahui peningkatan hasil belajar setiap siklus yang dilakukan guru.

Tahap Refleksi: Kegiatan yang dilakukan pada tahap ini, Peneliti melaksanakan diskusi dengan pengamat (observer) utuk merefleksi hasil observasi dan evaluasi yang dilakukan. Refleksi dilakukan untuk mengkaji hal-hal yang telah dicapai dan belum dicapai atau melihat apakah rencana telah terlaksana secara optimal dan perlu dilakukan perbaikan. Hasil refleksi digunakan untuk menetapkan langkah- 
langkah lebih lanjut pada siklus berikutnya.Data tentang pelaksanaan pembelajaran akan dianalisis secara deskriptif berdasarkan hasil observasi dari observer. Sedangkan data kuantitatif akan dianalsis dengan melihat hasil tes pada setiap akhir

\section{HASIL DAN PEMBAHASAN}

1) Perencanaan

mengacu pada penerapan model pembelajaran kontekstual yang akan digunakan dalam pelaksanaan tindakan. Adapun hal-hal yang dilakukan pada tahap ini adalah membuat RPP, membuat LKS, membuat lembar observasi untuk guru dan siswa, menyediakan alat dan media pembelajaran, membuat jurnal refleksi diri, dan menyusun tes siklus I.

\section{2) Pelaksanaan Tindakan Siklus 1}

\section{1) Pertemuan Pertama}

Pelaksanaan tindakan pertemuan pertama guru guru memulai pembelajaran dengan berdoa terlebih dahulu lalu mengabsen siswa, dan mempersiapkan materi ajar. Kemudian mengecek pengetahuan awal siswa dengan mengajukan beberapa pertanyaan yang berhubungan dengan materi yang akan diajarkan. Lalu memotivasi siswa agar lebih bersemangat untuk belajar, selanjutnya guru menyampaikan tujuan pembelajaran yang akan dicapai.

Pada kegiatan inti, sebelum masuk pada materi pembelajaran guru menggali pengetahuan awal siswa dengan melontarkanbebera pertanyaan '. Pengetahuan tindakan. Artinya apabila setiap akhir tindakan secara klasikal belum mencapai $70 \%$ dari KKM maka akan dilanjutkan pada siklus berikutnya, sampai mencapai indikator kinerja yang telah ditetapkan.

\section{Tindakan Siklus I}

Pada tahap ini, peneliti membuat instrument dan perangkat pembelajaran yang awal tersebut akan dijadikan acuan untuk menyelidikinya

(Construktivisme). Selanjutnya guru menjelaskan materi pembelajaran serta melontarkan pertanyaan yang bertujuan untuk memacu pemahaman siswa dengan menghubungkan antara materi dengan konteks keseharian siswa di lingkungannya (Questioning).

Kemudian dilanjutkan dengan kegiatan mengorganisasikan siswa menjadi 4 kelompok secara langsung dengan melihat deretan tempat duduk siswa dan menyuruh siswa membalik tempat duduknya membentuk kelompok yang terdiri dari 4 dan 5 orang (Learning Community), selanjutnya guru membagikan LKS, guru memberikan petunjuk cara menyelesaikan soal dan jika ada soal yang belum dipahami maka siswa diberi kesempatan untuk bertanya dan guru dapat memberikan penjelasan seperlunya, kemudian guru membimbing siswa agar dapat bekerja sama untuk berbagi ide cara penyelesaian soal (Inquiry). Pada pelaksanaan pembelajaran guru membimbing siswa dalam 
menyelesaikan soal-soal yang ada dalam LKS.

Setelah semua kelompok selesai menjawab soal-soal, maka guru mempersilahkan setiap kelompok untuk memanggil satu orang perwakilan kelompok untuk membacakan jawabannya, kelompok lain menanggapi. Guru memperjelas pembelajaran dengan menyimpulkan hasil diskusi. Sebelum mengakhiri pembelajaran, guru menanyakan kepada siswa hal-hal yang belum dipahami serta hal yang dapat menggangu jalannya proses pembelajaran berikutnya (Reflection). Lalu mengumpulkan hasil diskusi kelompok siswa, dilanjutkan dengan menilai hasil kerja kelompok serta menentukan kelompok terbaik dalam diskusi kelompok dan tak lupa guru memberikan pujian kepada kelompok terbaik (Autentic Asessment). Pada kegiatan akhir pembelajaran, guru bersama siswa menyimpulkan materi pembelajaran yang telah dipelajari. Lalu diakhiri dengan menyampaikan materi yang akan dipelajari pertemuan berikutnya.

\section{2) Pertemuan kedua}

Pelaksanaan tindakan siklus 1 pertemuan kedua guru Pada kegiatan awal, guru memulai pembelajaran dengan berdoa terlebih dahulu lalu mengabsen siswa, dan mempersiapkan materi ajar. Selanjutnya mempresentasekan hasil pekerjaanya di depan kelas dan menginformasikan kepada kelompok lain agar memberikan tanggapan sesuai dengan jawaban hasil kelompoknya (Modeling), kemudian guru memberikan apersepsi dengan menanyakan pembelajaran sebelumnya tentang pentingnya harga diri bagi seseorang. Lalu guru menyampaikan tujuan pembelajaran serta memotivasi siswa agar terlibat aktif dalam proses pembelajaran karena diakhir pembelajaran akan diadakan tes evaluasi, serta tak lupa guru menyampaikan kegiatan yang akan dilaksanakan selama pembelajaran berlangsung.

Pada kegiatan inti, sebelum masuk pada materi pembelajaran guru menggali pengetahuan awal siswa dengan melontarkan pertanyaan "Jika ada teman sekelasmu yang mendapatkan nilai ulangan yang bagus, bagaimanakah sikap kalian?”. Pengetahuan awal tersebut akan dijadikan acuan untuk menyelidikinya (Construktivisme). Selanjutnya guru menjelaskan materi pembelajaran serta melontarkan pertanyaan yang bertujuan untuk memacu pemahaman siswa dengan menghubungkan antara materi dengan konteks keseharian siswa di lingkungannya (Questioning).

Kemudian guru membagi siswa kedalam 4 kelompok yang heterogen 
dengan melihat siswa-siswa yang berprestasi dan membagi secara seksama antara yang berprestasi dan kurang berprestasi dan antara siswa perempuan dan laki-laki bertujuan agar semua anggota kelompok aktif yang terdiri dari 4 dan orang (Learning Community), selanjutnya guru membagikan LKS, guru memberikan petunjuk cara menyelesaikan soal dan jika ada soal yang belum dipahami maka siswa diberi kesempatan untuk bertanya dan guru dapat memberikan penjelasan seperlunya, kemudian guru membimbing siswa agar dapat bekerja sama untuk berbagi ide cara penyelesaian soal (Inquiry). Pada pelaksanaan pembelajaran guru membimbing siswa dalam menyelesaikan soal-soal yang ada dalam LKS.

Setelah semua kelompok selesai menjawab soal-soal, maka guru mempersilahkan setiap kelompok untuk mempresentasekan hasil pekerjaanya di depan kelas dan menginformasikan kepada kelompok lain agar memberikan tanggapan sesuai dengan jawaban hasil kelompoknya (Modeling), kemudian memanggil satu orang perwakilan kelompok untuk membacakan jawabannya, kelompok lain menanggapi. Guru memperjelas pembelajaran dengan menyimpulkan hasil diskusi. Sebelum mengakhiri pembelajaran, guru menanyakan kepada siswa hal-hal yang belum dipahami serta hal yang dapat menggangu jalannya proses pembelajaran berikutnya (Reflection). Lalu mengumpulkan hasil diskusi kelompok siswa, dilanjutkan dengan menilai hasil kerja kelompok serta menentukan kelompok terbaik dalam diskusi kelompok dan tak lupa guru memberikan pujian kepada kelompok terbaik (Autentic Asessment). Pada kegiatan akhir pembelajaran, guru bersama siswa menyimpulkan materi pembelajaran yang telah dipelajari. Selanjutnya guru memberikan soal sebagai tes siklus I pada setiap siswa untuk dikerjakan secara individu.

\section{3) Hasil Observasi dan Evaluasi Siklus} 1

Observer mengamati pelaksanaan tindakan siklus I pertemuan pertama dan pertemuan kedua sejak awal hingga akhir pembelajaran dengan menggunakan lembar observasi yang dibuat oleh peneliti. Hal-hal yang diobservasi pada pelaksanaan siklus I adalah aktivitas mengajar guru apakah sudah sesuai dengan skenario pembelajaran yang dibuat yaitu proses pembelajaran model kontekstual atau belum, selain itu juga melihat aktivitas belajar siswa dalam mengikuti pembelajaran serta hasil belajar siswa.. Hasil analisis observasi aktivitas mengajar guru adalah dari 15 aspek yang diamati hanya 10 aspek pembelajaran yang terlaksana dengan baik atau 66,67\%, sedangkan pertemuan kedua jumlah skor hasil aktivitas mengajar guru adalah dari 15 
aspek yang diamati hanya 11 aspek yang terlaksana atau 73,33\%. Hasil analisis observasi aktivitas belajar siswa pada siklus I pertemuan pertama jumlah skor hasil aktivitas belajar siswa yang dicapai adalah dari 15 aspek yang diamati hanya 10 aspek yang terlaksana dengan baik atau $66,67 \%$ dan pertemuan kedua jumlah skor hasil aktivitas belajar siswa yang dicapai adalah dari 15 aspek yang diamati terlaksana 11 aspek atau $73,33 \%$.

Data evaluasi hasil belajar siswa menunjukkan bahwa pemahaman siswa tentang materi yang telah diajarkan tersebut

Tabel 1. Hasil Analisis Ketuntasan Belajar Siswa Pada Siklus I.

\begin{tabular}{cccc}
\hline Skor & JumlahSiswa & Persentase (\%) & Keterangan \\
\hline $0-69$ & 5 & $26,32 \%$ & TidakTuntas \\
$70-100$ & 14 & $73,68 \%$ & Tuntas \\
Jumlah & $\mathbf{1 9}$ & $\mathbf{1 0 0 \%}$ & \\
Rata-rata & $\mathbf{7 1 , 5 8}$ & & \\
\hline
\end{tabular}

Sumber: Diolah dari hasil penelitian

\section{4) Refleksi}

Berdasarkan hasil observasi dan evaluasi pada pelaksanaan tindakan siklus I baik pertemuan I dan pertemuan II masih belum mencapai indikator kinerja yang telah ditetapkan dan masih terdapat kekurangan dan kelemahan . Adapun kekurangan dan kelemahan yang perlu diperbaiki terdiri dari 2 yaitu faktor guru danfaktor siswa.

Faktor guru terdiri dari guru masih kurang mampu dalam mengelola kelas, guru masih kurang dalam memberikan masih tergolong rendah karena belum memenuhi standar KKM yang ditetapkan oleh sekolah yakni $80 \%$ siswa telah mencapai nilai $\geq 70$. Hasil evaluasi siklus I siswa yang tuntas atau memperoleh nilai $\geq 70$ sebanyak 14 orang $(73,68 \%)$ dan yang tidak tuntas sebanyak 5 orang $(26,32 \%)$ dengan hasil belajar siswa mencapai ratarata 71,58 . motivasi kepada siswa, dalam pembagian kelompok guru tidak membagi kelompok secara heterogen, guru langsung menunjuk siswa yang duduk berdekatan sesuai deretan bangku untuk membentuk kelompok akibatnya ada kelompok yang cepat selesai dan ada kelompok yang lambat menyelesaikan soal, guru tidak mengorganisasi waktu belajar sesuai dengan apa yang telah direncankan pada skenario pembelajaran, serta guru masih kurang menguasai model kontekstual, 
sehingga susah dalam melakukan pembelajaran.

Faktor siswa yang terdiri dari siswa masih kurang aktif dalam kelompoknya, siswa banyak bermain dalam proses pembelajaran, sehingga membuat teman yang lain terganggu, ada sebagian siswa yang tidak senang dengan teman kelompoknya sehingga mereka mencari sendiri teman kelompoknya, setiap kelompok kurang menunjukkan kerjasama yang kompak dalam mengerjakan LKS, dan dalam mengerjakan LKS ada sebagian siswa bercerita dan bermain.

\section{Tindakan Siklus II}

\section{1) Perencanaan}

Berdasarkan hasil observasi, evaluasi dan refleksi pada tindakan siklus I, maka peneliti bersama observer kembali merencanakan siklus II dengan harapan kekurangan dan kelemahan pada pelaksanaan siklus I dapat diperbaiki sehingga diharapkan tindakan siklus II mengalami penyempurnaan.. Adapun halhal yang dilakukan pada tahap ini adalah membuat RPP siklus 2, membuat LKS , membuat lembar observasi untuk guru dan siswa, menyediakan alat dan media pembelajaran, membuat jurnal refleksi diri, dan menyusun tes siklus II.

\section{2) Pelaksanaan Tindakan}

\section{a. Pertemuan Pertama}

Pada kegiatan awal, guru memulai pembelajaran dengan berdoa terlebih dahulu lalu mengabsen siswa, dan mempersiapkan materi ajar. Kemudian mengecek pengetahuan awal siswa dengan mengajukan beberapa pertanyaan yang berhubungan dengan materi yang akan diajarkan. Lalu memotivasi siswa agar lebih bersemangat untuk belajar, selanjutnya guru menyampaikan tujuan pembelajaran yang akan dicapai serta menyampaikan kegiatan yang akan dilaksanakan selama pembelajaran berlangsung. Kemudian tak lupa guru menyampaikan kriteria penilaian kelompok serta guru akan menentukan kelompok terbaik diakhir pembelajaran.

Pada kegiatan inti, sebelum masuk pada materi pembelajaran guru menggali pengetahuan awal siswa dengan melontarkanpertanyaan "Apa saja contoh sikap penerapan harga diri disekolah?". Pengetahuan awal tersebut akan dijadikan acuan untuk menyelidikinya (Konstruktivisme). Selanjutnya guru menjelaskan materi pembelajaran serta melontarkan pertanyaan yang bertujuan untuk memacu pemahaman siswa dengan menghubungkan antara materi dengan konteks keseharian siswa di lingkungannya (Questioning).

Kemudian dilanjutkan dengan kegiatan mengorganisasikan siswa menjadi 4 kelompok sesuai dengan kelompok yang telah ditentukan pada pertemuan sebelumnya (Learning Community), 
selanjutnya guru membagikan LKS, guru memberikan petunjuk cara menyelesaikan soal dan jika ada soal yang belum dipahami maka siswa diberi kesempatan untuk bertanya dan guru dapat memberikan penjelasan seperlunya, kemudian guru membimbing terus siswa agar dapat bekerja sama untuk berbagi ide cara penyelesaian soal (Inquiry). Pada pelaksanaan pembelajaran guru membimbing siswa dalam menyelesaikan soal-soal yang ada dalam LKS.

Setelah semua kelompok selesai menjawab soal-soal, maka guru mempersilahkan setiap kelompok untuk mempresentasekan hasil pekerjaanya di depan kelas dan menginformasikan kepada kelompok lain agar memberikan tanggapan sesuai dengan jawaban hasil kelompoknya (Modeling), kemudian memanggil satu orang perwakilan kelompok untuk membacakan jawabannya, kelompok lain menanggapi. Situasi diskusi berjalan lancar dan semua kelompok sudah mulai terlihat perkembangannya dengan menanggapi jawaban temannya. Guru memperjelas pembelajaran dengan menyimpulkan hasil diskusi. Sebelum mengakhiri pembelajaran, guru menanyakan kepada siswa hal-hal yang belum dipahami serta hal yang dapat menggangu jalannya proses pembelajaran berikutnya (Reflection). Lalu mengumpulkan hasil diskusi kelompok siswa, dilanjutkan dengan menilai hasil kerja kelompok serta menentukan kelompok terbaik dalam diskusi kelompok dan tak lupa guru memberikan pujian kepada kelompok terbaik (Autentic Asessment). Pada kegiatan akhir pembelajaran, guru bersama siswa menyimpulkan materi pembelajaran yang telah dipelajari.

\section{b. Pertemuan kedua}

Pelaksanaan tindakan siklus II pertemuan kedua guru melaksanakan pembelajaran sesuai dengan skenario yang ada pada RPP siklus 2 kedua. Pertemuan ini alokasi waktunya $2 \times 45$ menit dengan rincian kegiatan awal 10 menit, kegiatam inti 60 menit dan kegiatan akhir 20 menit. Kegiatan awal pertama yang dilakukan guru menggali pengetahuan awal siswa, memotivasi siswa dan menanyakan hal-hal yang belum dipahami serta menjelaskan tujuan pembelajaran. Pada tahap awal ini siswa sangat antusias dan bersemangat sehingga pertanyaan apersepsi dapat dijawab dengan baik. Pada akhir pembelajaran guru bersama siswa menyimpulkan materi pelajaran dan siswa mencatat materi yang penting

\section{Observasi dan Evaluasi.}

Berdasarkan hasil pengamatan yang dilakukan oleh observer selama pembelajaran berlangsung pada pertemuan pertama jumlah skor hasil aktivitas mengajar guru adalah dari 15 aspek yang diamati hanya 13 aspek pembelajaran yang 
terlaksana dengan baik atau 86,67\%, diamati hanya 14 aspek yang terlaksana sedangkan pertemuan kedua jumlah skor hasil aktivitas mengajar guru meningkat yaitu terlaksana 15 aspek dari 15 aspek atau $100 \%$. Pada siklus II siswa terlihat antusias dalam mengikuti pembelajaran, siswa sudah memahami model pembelajaran yang diterapkan. Data hasil observasi kegiatan belajar siswa pada pertemuan pertama jumlah skor hasil aktivitas belajar siswa dengan baik atau 93,33\% dan pertemuan kedua jumlah skor hasil aktivitas belajar siswa yang dicapai adalah terlaksana 15 aspek dari 15 aspek atau 100\%. Pada akhir proses pembelajaran diadakan evaluasi atau tes akhir tindakan siklus II berupa tes tertulis yang dikerjakan secara individual untuk mengetahui peningkatan hasil belajar siswa.

yang dicapai adalah dari 15 aspek yang

Tabel 3. Hasil Analisis Ketuntasan Belajar Siswa Pada Siklus II.

\begin{tabular}{llll}
\hline Skor & JumlahSiswa & $\begin{array}{l}\text { Persentase } \\
(\mathbf{\%})\end{array}$ & Keterangan \\
\hline $0-69$ & 1 & $5,26 \%$ & TidakTuntas \\
$70-100$ & 18 & $94,74 \%$ & Tuntas \\
Jumlah & $\mathbf{1 9}$ & $\mathbf{1 0 0 \%}$ & \\
Rata-rata & $\mathbf{8 0 , 5 3}$ & & \\
\hline
\end{tabular}

Sumber : Diolah dari data penelitian

Berdasarkan tabel diatas, hasil tes yang terjadi pada setiap akhir menunjukkan bahwa pemahaman siswa pembelajaran. Berdasarkan hasil observasi tentang materi yang telah diajarkan tersebut menunjukkan ketuntasan hasil belajar dimana memenuhi standar KKM yang ditetapkan oleh sekolah yakni $80 \%$ siswa telah mencapai nilai $\geq 70$. Hasil evaluasi siklus II siswa yang tuntas atau memperoleh nilai $\geq 70$ sebanyak 18 orang $(94,74 \%)$ dan yang tidak tuntas sebanyak 1 orang $(5,26 \%)$ dengan hasil belajar siswa mencapai rata-rata 80,53 .

\section{4) Refleksi}

Refleksi merupakan proses atau tahap dalam penelitian tindakan kelas dimana bertujuan untuk memperbaiki kesalahan dan evaluasi pada pelaksanaan tindakan siklus II baik pertemuan I dan pertemuan II sesuai rencana yang telah ditetapkan sebelumnya, hal ini berdasarkan hasil diskusi anatara peneliti dengan observer (guru kelas) dimana terlihat bahwa pembelajaran dengan menerapkan model pembelajaran kontekstual sudah mendapatkan hasil yang lebih baik, meskipun ada satu orang siswa yang belum mencapai KKM. Akan tetapi siswa tersebut aktif dalam melibatkan diri dalam pelaksanaan tindakan kelompok. 
Jika dilihat dari hasil tes pada evaluasi tindakan siklus II, yaitu telah mencapai $94,74 \%$ dengan nilai rata-rata 80,53 telah memenuhi KKM dengan perolehan nilai $\geq 70$ dengan kata lain telah mencapai indikator keberhasilan yang ditetapkan oleh peneliti yaitu $80 \%$. Dengan demikian peneliti dan observer sepakat bahwa penelitian dihentikan sampai dengan siklus II.

\section{PEMBAHASAN}

Penelitian tindakan kelas ini terdiri dari dua siklus. Tiap siklus terdiri dari dua kali pertemuan, pada pertemuan kedua dilakukan tes evaluasi setiap siklusnya yang dilaksanakan sesuai dengan prosedur penelitian. Jumlah pertemuan dalam setiap siklus tersebut berdasarkan dari kepadatan materi yang dibahas. Pada penelitian tindakan kelas ini, kelompok sudah dibentuk sebagaimana mestinya. Siswa dibagi dalam 4 kelompok, setiap kelompok terdiri dari 5 siswa. Dalam penelitian ini melakukan kesepakatan antara observer dangan peneliti, maka yang mengajar adalah peneliti dan ada yang bertindak sebagai observer adalah guru kelas yang berpengalaman. Dari tes hasil belajar siswa pada siklus I siswa yang belum tuntas berjumlah 5 orang siswa atau sebesar 26,32\%, sedangkan siswa yang memperoleh nilai tuntas berjumlah 14 orang siswa atau sebesar $73,68 \%$ sehingga ketuntasan hasil belajar siswa siklus I mencapai 73,68\%. Pada pembelajaran siklus II, siswa yang belum tuntas berjumlah 1 orang atau sebesar 5,26\%, sedangkan siswa yang memperoleh nilai tuntas berjumlah 18 orang siswa atau sebesar 94,74\% sehingga ketuntasan hasi belajar siswa siklus II mencapai 94,74\%.

Hasil observasi aktivitas mengajar guru pada penelitian tindakan pembelajaran menjadi dasar untuk menentukan skor perolehan guru. Skor perolehan guru digunakan untuk menentukan persentase keberhasilan aktivitas mengajar guru. Pada siklus I pertemuan pertama adalah 10 dengan persentase keberhasilan sebanyak $66,67 \%$ dan pertemuan kedua adalah 11 dengan persentase keberhasilan sebanyak $73,33 \%$. Sedangkan siklus II petemuan pertama adalah 13 dengan persentase keberhasilan sebanyak $86,67 \%$ dan pertemuan kedua adalah 15 dengan persentase keberhasilan sebanyak 100\%.

Keberhasilan aktivitas belajar siswa pada tindakan siklus I pertemuan pertama, dari 15 aspek pembelajaran yang terlaksana hanya 9 skenario pembelajaran dan pertemuan kedua hanya mencapai 11 aspek pembelajaran. Dengan demikian, maka KABS pertemuan pertama hanya mencapai $60 \%$ dan pertemuan kedua mencapai 73,33\%. Keberhasilan aktivitas belajar siswa yang masih kurang pada tindakan siklus I disebabkan karena adanya beberapa kekurangan dan kelemahan yang telah 
diuraikan pada hasil refleksi pada siklus I. Setelah menerima saran-saran dari observer berdasarkan hasil diskusi pada kegiatan refleksi, maka peneliti mengadakan tindakan siklus II dengan penerapan model pembelajaran kontekstual. Pada siklus I pertemuan pertama adalah 9 dengan persentase keberhasilan sebanyak $60 \%$ dan pertemuan kedua adalah 11 dengan persentase keberhasilan sebanyak 73,33\%. Sedangkan siklus II petemuan pertama adalah 14 dengan persentase keberhasilan sebanyak 93,33\% dan pertemuan kedua adalah 15 dengan persentase keberhasilan meningkat sebanyak $100 \%$.

\section{KESIMPULAN}

Hasil penelitian menunjukan bahwa aktivitas siswa terhadap proses pembelajaran, terjardi peningkatan dari $73,68 \%$ dengan nilai rata-rata 71,58 pada siklus I dan siklus II hasil belajar siswa meningkat menjadi $94,74 \%$ dengan nilai rata-rata 80,53. Untuk aktivitas mengajar guru pada siklus I pertemuan pertama mencapai $66,67 \%$ dan pertemuan kedua meningkat menjadi $73,33 \%$, sedangkan pada siklus II pertemuan pertama mencapai $86,67 \%$ dan pertemuan kedua meningkat menjadi 100\%. Selanjutnya untuk peningkatkan aktivitas belajar siswa pada siklus I pertemuan pertama mencapai $60 \%$ dan pertemuan kedua meningkat menjadi 73,33\%, sedangkan pada siklus II pertemuan pertama mencapai $93,33 \%$ dan pertemuan kedua meningkat menjadi $100 \%$.

\section{DAFTAR PUSTAKA}

Aunurrahman. 2010. Belajar dan Pembelajaran. Bandung: Alfabeta.

Aqib, Zainal dkk. 2010. Penelitian Tindakan Kelas Untuk Guru SD, $S L B, T K$. Bandung: Yarama Wijaya.

Depdiknas. 2003. Pendekatan Pembelajaran Kontekstual. Jakarta: Dirjen Depdiknas.

Dimyanti dan Mudjiono. 1999. Belajardan Pembelajaran. Jakarta: Rineka Cipta.

Hamalik, Oemar. 2006. Proses Belajar Mengajar. Bandung: BumiAksara.

Hartono, Rudi. 2013. Ragam Model Mengajar yang Mudah Diterima Murid. Yogyakarta: Diva Press.

Kuswartinah, Ruliana. 2009. Ayo Belajar Kewarganegaraan Untuk Kelas III $S D$ dan MI. Solo: PT Tiga Serangkai Pustaka Mandiri.

La Iru \& Arihi. 2010. Analisis Penerapan Pendekatan, Metode, Strategi, dan Model-Model Pembelajaran.

Kendari: Multi Presindo.

La Ode Rafiuddin R. 2010. Strategi Pembelajaran IPS SD. Kendari: Universitas Haluoleo.

Leni.2011. Penerapan Model Pembelajaran CTL (Contextual Teaching and Learnig) Dalam Meningkatkan Hasil Belajar PKn Materi Organisasi Siswa Pada Kelas V SDN 5 Kendari.Kendari: FKIP UHO. Tidak Diterbitkan.

Nasution, S. 2006. Berbagai Pendekatan dalam Proses Belajar Mengajar. Bandung: Bumi Aksara.

Putra, Rizema Sitiatava. 2013. Desain Belajar Mengajar Kreatif Berbasis Sains. Yogyakarta: Diva Press.

Rahmaniar. S. 2011. Belajardan Pembelajaran.Kendari:

UniversitasHaluoleo.

Rusman. 2014. Model-Model Pembelajaran. Jakarta: PT RajagrafindoPersada. 
Sunarso.2008. Pendidikan

Kewarganegaraan Kelas 3 Sekolah Dasar. Bogor: Yudhistira.

Suparno. 2008. Teori Perkembangan Kognitif Jean Piaget. Yogyakarta: Kanisius.

Syam, Noor. 2006. Pedoman Guru Pendidikan Kewarganegaraan untuk SD dan MI Kelas VI. Malang: PT Mustika Perkasa Utama.
Trianto.2010. Mendesain Model PembelajaranInovatif-

Progresif.Surabaya: Kharisma Putra utama.

Usman Uzer dan Setiawati Lilis. 1993. Upaya Optimalisasi Kegiatan Belajar Mengajar. Bandung: Remaja Rosdakarya.

Winataputra. 2007. Belajar dan Pembelajaran. Jakarta: Departemen Pendidikan dan Kebudayaan. 